\title{
ARENA (KRITIK) SASTRA INDONESIA: STUDI KASUS PADA JURNAL POETIKA FIB UNIVERSITAS GADJAH MADA
}

\author{
Dharma Satrya HD. \\ Sekolah Tinggi Keguruan dan Ilmu Pendidikan Hamzanwadi NTB \\ Email: dharma_hd@yahoo.co.id
}

\begin{abstract}
Abstrak
Tulisan ini membahas tentang jurnal sebagai arena kritik sastra. Di dalam jurnal terjadi praktik legitimasi posisi, sebagai penulis, kritikus atau akademisi. Pendudukan dan pengambilan posisi dilakukan oleh agen-agen dalam jurnal tersebut. Dalam tulisan ini ditemukan bahwa akademisi melegitimasi penulis dan sebaliknya penulis yang menjadi akademisi melegitimasi penulis lainnya, dan bahkan akademisi mengkritik akademisi lainnya yang berada dalam arena lain, dan dimungkinkan juga dalam arena yang sama. Dalam arena kritik, pertukaran posisi terus berlangsung selama ada arena tergantung dari penguasa arena, yaitu Faruk sebagai agen dalam kekuasaan simbolik dan yang mana kekuasaan itu bahkan identik dengan dirinya. Dalam arena (kritik) sastra Indonesia, dan khususnya Universitas Gadjah Mada, Faruk membawa arena (kritik) sastra Indonesia ke arah baru dengan sudut pandang baru untuk membawa teks sastra ke arah perspektif yang lebih baru yang identik dengan kebaruan pandangannya dan yang merupakan bagian dari habitusnya dalam dunia sastra Indonesia.
\end{abstract}

Kata kunci: Arena, Praktik, Posisi.

\section{Abstrack}

This paper discusses the journal as an arena for literary criticism. In the journal the practice of legitimacy is occurred, as a writer, critics or academics. Taking and making positions are conducted by the agents of the journal. This study found that in Jurnal Poetika, academics legitimize the writer and conversely the writer who became the academics legitimize the other writer and even criticize the other academics in their different arena, and it is also possible in the same arena. In the arena of criticism, the exchange of positions continues as long as the existence of the arena, depends on the authorities of the arena, with Faruk as the agent of symbolic power, and even the power is identical to bimself. In the arena (criticism) of Indonesian literature especially in the University of Gadjah Mada, Faruk brings the arena (criticism) of Indonesian literature to a new direction with a new angle to bring the literary text towards newer perspective that is identical to the newer view which is a part of the habitus in Indonesian literature.

Keywords: Arena, Practice, Positions.

\section{Pendahuluan}

Ada kalimat menarik dalam buku Metode Penelitian Sastra karya Faruk. Dalam buku itu Faruk (2012:178) mengatakan bahwa kritik sastra tidak lebih dari komentar yang mempertanyakan persoalan apa yang dikatakan oleh teks, apa yang ingin dikatakan oleh teks, dan dengan demikian kritikus menyingkapkan makna yang lebih dalam yang menunjuk kepada "kebenaran esensial", kebenaran yang sedang mati suri di dalam atau di balik teks dan yang membutuhkan kritikus untuk menghidupkannya (kembali). Siapa yang akan mengatakan bahwa suatu teks itu hidup dan dihidupkan kalau bukan seorang kritikus, atau kalau tidak melalui sebuah komentar. Kalau melihat suatu teks secara ontologis, maka teks ada atau hadir hanya jika dihadirkan. Tanpa ada komentar, tanpa ada kritik, teks sastra bukanlah apa-apa dan tak berarti apa-apa, sehingga aktivitas kritik menjadi syarat keberadaan dan kehadiran suatu teks.

Dalam sejarah kesusastraan, teksteks menjadi hidup dan dihidupkan oleh kehadiran kritikus, misalnya bagaimana teksteks sastra tradisi Balai Pustaka diangkat dan dihidupkan kembali melalui kritik Faruk (2012) dalam disertasinya dengan metode dekonstruksinya, bagaimana teks-teks sastra diangkat kembali oleh Taum (2012) dalam disertasinya dengan menyandingkannya dengan tek-teks nonsastra sebagai teks yang sejajar, bagaimana kemudian Aprinus Salam (2010) dalam disertasinya mengangkat teks-teks sastra 


\section{Jurnal Poetika Vol. III No. 2, Desember 2015}

dengan menghubungkannya dengan negara dan perubahan sosial, juga yang dilakukan oleh Pujiharto (2010) dengan perspektif pascamodernnya. Kritik sastra muncul dalam jurnal-jurnal seperti bagaimana teks sastra diangkat atau dihidupkan kembali dengan berbagai macam perspektif yang membuat pembaca atau kritikus, dan bahkan penulisnya semakin hidup dan terus dihidupkan kembali dalam dan melalui teks sastra dengan cara pandang baru seperti yang dilakukan Jurnal Poetika.

Pada 2013, Jurnal Poetika mengangkat teks-teks sastra dengan perspektif yang relatif baru seperti tawaran kajian sosial dari Kukuh, kajian budaya media dari Prasisko, dekonstruksi dari Mashuri, Akmal dengan tawaran kritik marxisnya. Selanjutnya pada edisi berikutnya, muncul kritik yang lebih baru seperti tawaran Purnomosasi dengan konsep Claudio Guillenya, Fawaid dengan etika Levinansiannya, Fathoni dengan tawaran Stephen Greenblattnya.

Pada 2014, teks-teks sastra dihidupkan kembali dengan munculnya kajian realism magis. Saputra mengangkat kembali novel Salman Rusdie, Alexander menghidupkan karya Maxine Hong Kingston, Kadir dengan novel Perempuan Poppo, dan Iswandari dengan puisi Gendhing Pulebahasan. Pada edisi berikutnya dapat dilihat bagaimana Suciati menghidupkan kembali The God of Smaal Things, Woodrich yang mempermasalahkan Cina dengan masalah cinta, Adzani dengan konstruksi ruang kota dalam novel The Kite Runner, Raharyoso dengan paradoks ruang tubuhnya, dan Dwiwardani dengan ruang pascakolonial dalam Kitchen, hal yang sama dengan kritik dari Purwanti. Semua kajian itu melihat teks sastra dalam satu bingkai, yaitu pascakolonial. Hal demikian terjadi pada edisi setelahnya dengan mengangkat persoalan nasionalisme, pergeseran kekuasaan, serta ruang dan kota beserta kemungkinan keberadaannya.

Teks-teks dan kritik atas teksteks tersebut menjadi satu di antara banyak kemungkinan jawaban dari tulisan
Aprinus Salam yang mempertanyakan arah perkembangan kritik sastra, juga tentang posisi dan arah perkembangan paradigma ilmu sastra dalam menilai atau mengkritik teksteks sastra. Persoalan kritik menjadi persoalan penting dalam melihat pergerakan teks-teks sastra. Kritik menjadi sebuah arena perjuangan merebut posisi dan legitimasi atas teks sastra yang hidup dan yang dihidupkan, dan bahkan perjuangan merebut legitimasi sebagai agen yang menghidupkan teks. Kasus Jurnal Poetika memperlihatkan sebuah kekuasaan simbolik dan kultural dari seorang ilmuan sastra yang menjadi pengelola studi S2 Sastra dan pimpinan umum jurnal, yaitu Faruk. Dengan kekuasaannya, ia membawa dunia kritik, dunia akademik sastra ke arah sebuah pandangan baru atau paradigma baru, yaitu pascastrukturalisme, pascakolonialisme, dan pascamodernime, yang semua itu terstruktur dalam diri Faruk sebagai seorang ilmuan sastra, yang tercermin pada hampir semua bukunya dengan titik keberangkatan pada disertasinya. Persoalan itu menjadi habitusnya yang membuatnya membawa arena sastra ke arah keseimbangan dunia, dunia penulis, kritik atau akademik, yang dalam pergulatannya terjadi pertukaran posisi.

Kritik sastra sebagai ruang yang di dalamnya teks sastra (dan bahkan penulisnya atau pengkritiknya) mendapatkan legitimasi dirinya, posisinya sebagai karya kebudayaan yang mempunyai arti. Kritik menjadi arena mengangkat teks sastra ke atas kemudian menghidupkannya kembali ke permukaan dan membawanya ke dunia yang lebih baru dengan cara pandang baru. Dengan demikian, legitimasi karya melalui kritik dan sekaligus legitimasi penulisnya, dan bahkan melegitimasi yang mengkritik. Implikasinya adalah teks sastra menemukan dirinya, identitasnya, dan bahkan keberadaannya dalam ruang yang terus bergerak, ruang yang tidak akan selesai didefinisikan selama kritik terus berkembang dan bergerak, sehingga persoalan legitimasi juga terus bergerak. Dengan demikian, arena sastra 


\section{Jurnal Poetika Vol. III No. 2, Desember 2015}

adalah arena yang hidup dengan menjadikan kritik sebagai sebuah arena sastra.

Kritik adalah ruang pergulatan mendapatkan posisi-posisi. Melalui kritik, karya sastra atau seni memperoleh legitimasi atas keberadaannya. Legitimasi hanya bisa diberikan oleh seseorang atau sekolompok orang atau institusi tertentu yang memiliki banyak modal, baik kultural maupun simbolik dan bahkan ekonomi. Dalam Jurnal Poetika, Faruk sebagai pemegang modal yang menentukan apa dan siapa yang akan dimasukkan. Dunia akademik seperti universitas melakukan praktik legitimasi. Dunia sastra membutuhkan akademisi atau kritikus untuk memberikannya sebuah atribut atau legitimasi berupa sebuah prestise sebagai karya atau penulis yang dalam perspektif tertentu mempunyai arti penting bagi peradaban bersastra atau berkesenian. Dalam hal akademik, hal tersebut dicapai misalnya melalui jurnal ilmiah sastra.

Para intelektual Indonesia berlombalomba mendapat posisi dalam arena sastra, misalnya sastra FIB UGM yang dalam sejarah kajian sastra sangat berpengaruh. Hal tersebut dapat dilihat dari bagaimana kemudian capaian sastra FIB UGM ikut andil dalam mengantarkan UGM ke gerbang internasional pada tahun 2006 yang berimplikasi pada legitimasi simbolik kesarjanaan. Tidak hanya itu, dalam sejarah kesusastraan, sastra UGM secara kultural dan simbolik mencetak sastrawan dan kritkus sastra yang dalam perkembangan dan pergerakannya kemudian menjadi sebuah habitus. Implikasi praktisnya, sastra FIB UGM dalam arena (kritik) sastra Indonesia memiliki posisi sentral dalam pasar ekonomi simbolik kesusastraan. Dia bukan saja mencetak sastrawan dan kritikus, tetapi juga ilmuwan sastra. Posisi yang demikian disebabkan karena UGM memberikan sebuah arena dimana semua orang bersaing memperebutkan sebuah posisi menjadi sastrawan, akademisi atau kritikus sastra, dan bahkan menjadi ilmuwan sastra.

Arena sastra atau seni adalah arena kekuatan, tetapi juga arena pergulatan yang cenderung mengubah atau melanggengkan arena kekuatan ini (Bourdieu, 2012: 5). Konsep demikian memunculkan pertanyaan siapa yang memiliki kekuatan dan bagaimana kekuatan itu beroperasi atau mendapatkan kekuatannya. Di dalam arena tentunya akan ada perjuangan memperebutkan posisi sebagai yang kuat dan atau ingin menjadi kuat, sehingga di dalam arena sering terjadi pengambilan posisi. Bourdieu (2012: 5) menjelaskan ada ruang pengambilan dan pendudukan posisi di dalam sebuah struktur. Posisi-posisi yang ada memungkinkan terbentuknya arena yang lain dan dalam bentuk yang lain. Sebenarnya adanya posisi inilah yang memunculkan dan membentuk arena.

Ilmu tentang arena adalah analisis situs yang menetapkan bahwa setiap posisi didefinisikan secara subjektif oleh sistem properti distingtif yang melaluinya satu posisi disituasikan di antara posisi yang lain (Bourdieu, 2012: 4). Persoalannya adalah apakah antara yang menetapkan dan yang ditetapkan ada secara terpisah atau memiliki hubungan? Arena hadir tidak dalam kondisi yang begitu adanya, tetapi terstruktur dan distrukturkan. Bourdieu (2012: 5) menjelaskan bahwa struktur arena adalah ruang posisi-posisi, struktur distribusi modal properti-properti spesifik yang mengatur keberhasilan di dalam arena dan memenangkan laba spesifik (seperti prestise sastra) yang dipertaruhkan di dalamnya. Struktur bukanlah sesuatu yang tetap, melainkan sewaktu-waktu bisa berubah. Untuk memahami praktik-prakik para penulis dan seniman, bukan cuma produk mereka, kita harus mengerti kalau mereka adalah hasil pertemuan dua sejarah: sejarah posisi-posisi mereka dan sejarah disposisi mereka (Bourdieu, 2012: 52). Terdapat ruang kemungkinan dalam sejarah posisi-posisi, dan perubahannya, sebagaimana dijelaskan Bourdieu (2012: 8), terjadi dalam ruang kemungkinan itu sebagai hasil dari perubahan relasi kekuasaan yang membentuk ruang posisi-posisi. Posisi-posisi menjadi bagian dari 


\section{Jurnal Poetika Vol. III No. 2, Desember 2015}

arena yang di dalamnya penulis mengambil bagian. Karya sastra atau seni menjadi bagian dari arena, sebagaimana dijelaskan Bourdieu (2012:13) bahwa ia adalah objek yang eksis lantaran keyakinan (kolektif) yang mengenali dan mengakuinya sebagai sebuah karya seni.

\section{Kritik sebagai Praktik Legitimasi}

Kritik sebagai praktik legitimasi dapat dilihat pada bagaimana melegitimasinya dan siapa saja yang dilegitimasi. Dalam jurnal ilmu sastra Poetika, praktik legitimasi sebagai sebuah bentuk kekuasaan seringkali dilakukan terlebih oleh institusi tertentu yang ingin memenangkan sebuah arena. Kritik kemudian menjadi sebuah alat legitimasi.

Jurnal terbitan pertama, Juli 2013, belum menemukan bentuknya. Artinya, jurnal hadir tidak dengan karakteristik khas. Sajiansajian dalam kritik masih belum jelas ke arah mana akan dibawa. Arah itu seiring waktu akan jelas dan diperjelas. Pada edisi pertama, muncul Ramayda Akmal dan Mashuri. Mereka berdua hadir sebagai seorang kritikus sastra. Di lain sisi, Akmal dan Mashuri berstatus tidak hanya sebagai seorang kritikus tetapi juga seorang novelis dan penyair. Sebagai kritikus ia harus melakukan praktik kritik. Mashuri dalam kepenyairan cukup mendapat tempat dalam arena sastra di Jawa Timur, sedangkan Akmal dalam hal karya sudah mendapatkan posisi dalam arena sastra nasional dengan diberikannya penghargaan pada novelnya yang berjudul Jatisaba tahun 2010. Sebagai seorang akademisi, Mashuri mencoba menawarkan konsep dekonstruksi dalam membaca wayang, sedangkan Akmal, sebagai seorang akademisi, mencoba memperkenalkan teori Frederik Jameson dan aplikasinya dalam kritik sastra.

Pada edisi berikutnya, muncul Kris Budiman dengan mengangkat kembali puisi Rendra dan membacanya ulang. Kris Budiman hadir dalam jurnal Poetika tidak hanya sebagai seorang kritikus tetapi juga sebagai seorang novelis. Novelnya muncul pada volume III sebagai karya mutakhir dan dilegitimasi sebagai penulis sastra perjalanan. Pada volume I akademisi membicarakan Subagio Sastrowardoyo dalam dua tulisan. Zen Hae (2013: 117) mengatakan bahwa baru Subagio lah yang sejak awal menegaskan betapa pentingnya intelektualisme dalam puisi. Pada tulisan berikutnya, Prasetyo (2013) memperkuat posisi Subagio sebagai salah satu kritikus sastra Indonesia terpenting, cerdas, tekun, tapi juga berani dan bertanggung jawab. Pada tulisan setelahnya, pada kasus Kris Budiman terjadi hal yang sama, yaitu mengangkat kembali Rendra dengan melakukan pembacaan ulang karena tidak sepakat pada kritik Teeuw terhadap Rendra. Menurut Teeuw sebagaimana dijelaskan Kris Budiman (2013: 143), Rendra dalam puisi pamfletnya tidak banyak menyodorkan metafora dan perumpamaan, kalaupun ada menurutnya bersifat konvensional dan tidak mengejutkan, tidak membawa inovasi yang merombak konvensi puisi. Kris Budiman (2013: 143) tidak sepakat dengan penilaian Teeuw, sehingga membuatnya harus membaca ulang Rendra dan menyatakan pendapatnya yang berbeda, yaitu Rendra mempunyai kekuatan grafis metafora dan figur retorik lain dalam "Sajak Sebatang Lisong." Selain hal penting di atas, pada volume itu muncul sebuah tawaran kajian, yaitu sastra banding Claudio Guillen, etika Levinansian, dan puitika kultural Stephen Greenblatt.

Pada volume yang kedua tahun 2014, jurnal Poetika mengangkat isu baru dalam kajian sastra, yaitu realisme magis. Pada jurnal itu, Salman Rusdie dan Toni Morrison diangkat lagi ke permukaan dengan perspektif yang lebih baru. Iswandari dan Burhan Kadir mengangkat karya penulis Indonesia, Dul Abdul Rahman dan Badarudin Emce. Alexander dan Iswandari dalam jurnal itu hadir sebagai akademisi yang mengkaji secara teoritis karya tersebut. Ada satu hal yang pasti pada setiap edisi, yaitu adanya tawaran kajian baru dan adanya praktisi yang sekaligus akademisi, sehingga praktik legitimasi 
terus berlangsung. Akademisi melegitimasi praktisi, dan akademisi yang menjadi praktisi dilegitimasi oleh akademisi lagi. Akademisi yang muncul kemudian mengangkat kembali ke permukaan praktisi sastra yang dalam pengertian tertentu sedikit tenggelam. Bagimana mengangkatnya? Kajian-kajian yang baru atau teori-teori kritik yang relatif baru memberikan peluang untuk mengangkat kembali praktisi sastra yang tenggelam seperti pada kasus Toni Morison, Salman Rushdie, dan Rendra. Kajiankajian yang baru mengangkat kembali akademisi yang menjadi praktisi di kemudian harinya seperti pada kasus Kris Budiman. Bukan pada kasus praktisi yang mengakademis saja, tetapi juga pada kritikus yang dikukuhkan lagi sebagai kritikus, artinya diperkuat lagi posisinya seperti pada kasus Subagio Sastrowardoyo. Begitulah praktik legitimasi berlangsung antara penulis atau praktisi sastra dan akademisi sastra atau kritikus sastra. Untuk melanggengkan kekuasaan seorang penulis, misalnya saja Salman Rushdie dan Toni Morrsion, praktik legitimasi harus tetap berlanjut di dalam sebuah arena (kritik). Untuk melanggengkan kekuasaan seorang akademisi atau kritikus, praktik legitimasi kritiknya harus diperbaharui seperti bagaimana Kris Budiaman memperkuat kembali Rendra dan seperti bagaimana Zen Hae dan Prasetyo memperkuat posisi Subagio Sastrowardoyo sebagai kritikus.

\section{Akademisi dan Praktisi dalam Dua Sejarah}

Praktik Legitimasi adalah sebuah hasil pertemuan dua sejarah yang tentunya bersifat habitus. Dalam sejarah berdirinya Fakultas Ilmu Budaya, pendirinya adalah tokoh-tokoh yang gagasan, prinsip, dan kiprahnya terpantul terutama pada bidang sastra dan budaya. Beberapa di antaranya adalah R. Prijana sebagai ahli sastra dan filsafat Jawa, R.M.Ng Poerbatjaraka sang pembuka misteri Sastra Jawa Kuno, P.J. Zoetmulder. Selain itu, muncul sesudahnya, Baroroh Baried, Sulastin Sutrisno, Chamamah Soeratno, Kuntowijoyo, Umar
Kayam, Pradopo, dan Soemanto (Atmosudiro, 2006).

Dalam dunia sastra Indonesia, Umar Kayam lebih familiar sebagai seorang sastrawan daripada ilmuwan. Berbeda dengan Umar Kayam, Pradopo lebih dikenal sebagai kritikus yang buku-bukunya menjadi bacaan wajib bagi jurusan sastra Indonesia. Pradopo dalam disertasinya membicarakan tentang kritik sastra Indonesia modern. Dengan semakin menuanya Pradopo dan seiring berjalannya waktu, muncul Faruk sebagai ilmuwan sastra. Sebagai ilmuwan, Faruk sudah tentu mempunyai modal yang signifikan sebagai penentu dan bahkan pelegitimasi akademisi sastra. Dengan berkembangnya dunia intelektual Indonesia, Faruk dengan akumulasi modalnya, baik modal sosial, kultural, dan bahkan modal simboliknya membuat sebuah ruang kritik dalam bentuk jurnal ilmiah sastra dimana ia menjadi pimpinan umumnya. Jurnal itu dibuatnya pada Juli 2013.

Poetika sebagai jurnal ilmu sastra adalah sebuah situs yang di dalamnya posisi diberikan, didefinisikan, ditentukan, dan bahkan dipertukarkan. Tidak menutup kemungkinan akan terjadi pengambilan atau pergeseran posisi. Kondisi demikian akan memberikan ruang untuk terjadinya pertarungan. Apa yang dikejar? Sebuah legitimasi atau lebih tepatnya sebuah prestise sebagai akademisi atau kritikus. Dalam sejarah kesusastraan, Universitas Gadjah Mada memenangkan pertarungan itu dan mengambil semua posisi itu. Dalam buku Repertoire Fakultas Ilmu Budaya, pada bab Kiprah Alumni, Rendra dan Sapardi masuk sebagai alumni dengan kiprah yang meruang dan mewaktu. Pertanyaannya, bagaimana sekarang? Siapa saja yang dicetak Universitas Gadjah Mada? Adakah yang menandingi Umar Kayam, Rendra, Sapardi? Hal itu bisa dipersoalkan dan bisa juga tidak. Dunia sastra sekarang sudah jauh berbeda dengan dunia sastra masa lalu. Perkembangan teori membuat praktik yang berbeda pada karakterisktik individu atau kelompok tertentu, misalnya saja bagaimana 


\section{Jurnal Poetika Vol. III No. 2, Desember 2015}

Denny JA menjadi satu di antara 33 tokoh sastra berpengaruh yang dengan modal ekonominya mau mengubah atau memperbaharui peta sejarah sastra Indonesia dengan memasukkan dirinya sebagai salah satu tokoh. Perkembangan ilmu pengetahuan dan teknologi membuat orang-orang bisa dengan cepat mencetak dan atau mempublikasikan novel atau bukunya. Dengan banyaknya modal, arah perkembangan dunia sastra bisa saja dibelokkan atau diganti dan dengan mudahnya akses media, orang dengan mudah melakukan kritik sehingga tidak terpusat pada satu pusat, misalnya saja Jakarta atau Yogyakarta. Apa yang terpenting sekarang adalah mengedepankan kepentingan dan kebutuhan pemilik modal. Pada kasus jurnal Poetika, yang terpenting adalah selera dari pemilik modal, yaitu Faruk.

Orang-orang di balik jurnal berselera pada sesuatu yang baru dan sesuatu yang harus dibarukan. Hal tersebut bisa sesuatu yang diobjektivasi dan bisa sesuatu yang mengobjektivasi. Konsep ini ditawarkan Bourdieu dalam eksperimen sosiologisnya dengan mempergunakan apa yang diajarkan oleh ilmu sosial tersebut tentang dunia sosial dimana ilmu sosial diproduksi untuk mengontrol efekefek determinisme yang mempengaruhi semesta tersebut, sekaligus terhadap ilmu sosial tersebut (Bourdieu, 2011: 121). Di sini akan dilihat sudut pandang yang mengobjektivasi. Sudut pandang dalam jurnal tersebut adalah melihat sesuatu yang baru dan yang akan dibarukan. Penerbitan yang pertama sampai yang terakhir adalah sudut pandang baru untuk melihat yang baru dan yang lama. Hal ini bisa dilihat dari Kukuh dengan teori Bourdieu, Mashuri dengan dekonstruksi, Akmal dengan Jameson, Fawaid dengan Levinansian, Fatoni dengan Greenblat, Purnomosasi dengan Guillion, Volume II dengan kajian realisme magis dan pascakolonial Sara Upstone, dan Volume III dengan kajian Travel Writing. Kalau melihat pola yang terbentuk dalam jurnal tersebut, maka yang terpenting adalah sudut pandangnya yang baru atau perspektifnya, dengan kata lain cara mengobjektivasinya. Yang diobjektivasi bukanlah permasalahan jika ia sesuatu yang baru atau lama. Dengan sudut pandang yang baru, akan dapat dilihat arah perkembangan arena sastra Indonesia. Dengan memakai sudut pandang yang baru, dunia sastra dan kritiknya berjalan terus ke arah dan tempat yang baru. Implikasinya, ia membuka sebuah tempat atau wilayah yang baru sebagai alternatif bagi tempat lama atau dunia lama. Pada fase itu akan dimungkinkan arena (kritik) sastra Indonesia yang baru pula dengan pertarungan yang baru dan tentunya dengan orang yang baru.

Pada akhirnya nanti, sudut pandang baru ini akan menjadi sudut pandang lama. Tetapi yang penting di sini, dalam arena produksi kultural adalah sebuah kekuatan atau pertarungan, yaitu bertarung untuk mencapai atau memiliki yang baru. Pada level ini jurnal Poetika menunjukkan kekuatannya untuk bisa sampai pada cara pandang baru melihat penulis atau kritik baru dan penulis atau kritik lama yang kemudian dibarukan.

\section{Kepentingan dalam Jurnal Poetika}

Bourdieu (2011: 136) mengatakan bahwa kepentingan akan selalu ada selama ada arena sebagai ruang permainan yang terbentuk secara historis beserta institusi spesifiknya dan hukum-hukum keberfungsiannya sendiri. Artinya, kepentingan menyebabkan terbentuknya sebuah arena. Arena dalam dunia akademik sastra adalah pertarungan di dalam sebuah jurnal untuk mendapatkan legitimasi dan bahkan menjadi prasyarat untuk dapat menyelesaikan sebuah program akademik, baik pada level lokal, nasional, dan bahkan internasional. Sejak 2008 Universitas Gadjah Mada diberi wewenang untuk memberikan legitimasi kesarjanaan yang menginternasional seperti master of art dan master science. Dalam beberapa tahun terakhir UGM menduduki predikat sebagai universitas terbaik yang diakui oleh beberapa pihak. 
Kondisi demikian membutuhkan usaha untuk mempertahankan dan mengisi pengakuan tersebut dengan tanggung jawab akademik yang tinggi. Sebagai bentuk tanggung jawab dalam bidang ilmu sastra, mahasiswa pascasarjanan ilmu sastra di bawah pengelolaan Faruk menghadirkan jurnal itu sebagai media atau alat akademik dan bahkan sebagai sebuah strategi dalam mendudukkan posisiposisi. Pendudukan Kris Budiman sebagai kritikus dan sebagai penulis, pendudukan Akmal sebagai akademisi dan novelis, adalah sebuah strategi reproduksi peningkatan modal bagi mereka sebagai seorang agen. Bagaimana Kris Budiman mengobjektivasi Rendra dalam tulisannya, dan bagaimana Zen Hae dan Prasetyo mengobjektivasi Subagio Sastrowardoyo, bagimana kemudian Akmal mengobjektivasi Frederic Jameson, bagimana kemudian mahasiswa pascasarjanan ilmu sastra pada volume II, nomor 1, 2, dan 3 berbicara isu baru tentang realisme magis Faris dan pascakolonial Sara Upston, dan bagaimana isu pada volume III dengan tawaran teoritis tentang Travel Writing Carl Thomson, semua itu tidaklah begitu adanya dengan sendirinya, tetapi tergantung pada kepentingan sang sosiolog ilmuwan sastra, yaitu Faruk sebagai pengelola program pascasarjana Ilmu Sastra dan sebagai pimpinan umum jurnal Poetika. Praktik tersebut sebagaimana dijelaskan Bourdieu (2011: 140) merupakan hasil dari pertemuan antara habitus dengan arena, yaitu antara dua sejarah yang disesuaikan kurang lebih secara lengkap. Dalam hal ini, habitus Fakultas Ilmu Budaya Universitas Gadjah Mada dan posisinya dalam arena sastra nasional, dan arena (kritik) sastra Yogyakarta khususnya.

Agen-agen yang diobjektivasi dan yang mengobjektivasi juga terikat pada sebuah kepentingan, yaitu legitimasi diri sebagai sang sosiolog kritik atau sosiolog akademik dengan memaparkan sebuah teks sebagai entitas yang terus bergerak dan digerakkan. Hal itu dilakukan dalam rangka sebuah akumulasi modal atau investasi modal, baik yang sifatnya simbolik maupun kultural, tidak menutup kemungkinan juga modal ekonomi. Tidak hanya itu, strategi demikian menjadi cara menemukan sifat hakikinya dalam sebuah sejarah. Bourdieu (2011: 140) mengatakan bahwa agen tinggal membiarkan dirinya mengikuti hakikat sosialnya sendiri, yaitu hakikat mereka sebagaimana yang telah dibentuk sejarah, membiarkan diri mereka secara alamiah sesuai dengan dunia historis yang mereka hadapi untuk berbuat apa yang harus mereka perbuat, untuk mewujudkan kemungkinan masa depan yang telah termaktub dalam dunia tempat dimana mereka nyaman seperti 'ikan dalam air'. Tanpa melakukan kritik, tanpa ada media atau alat dalam bentuk jurnal, maka dunia akademik, dunia kritik, dan dunia teoritis akan berada dalam dunia 'ikan tanpa air' dan dengan dengan demikian dunia universitas menjadi dunia tanpa arena, tanpa struktur arena. Bagaimana dunia universitas dimungkinkan? Sastra dengan dunia kritiknya menjadi akan termultimediakan, seperti bagaimana kritik melalui multimedia bisa merekam dan kemudian mempublikasikannya dalam dunia maya yang semua orang bisa mengambilnya dan menjadikan strategi, sehingga akan muncul strategi kritik melalui multimedia berbasis teknologi. Kasus di atas membawa dunia kritik dan sosiologi kritik ke dalam dua arah yaitu, kritik yang terliterasikan dan kritik yang termultimediakan. Implikasinya, arena sastra menjadi semakin luas dan orangorang bisa bertarung dalam dua arah tersebut.

\section{Sastra UGM dan Kuasa Simbolik}

Studi sastra harus bisa menjadikan teks sastra dan penulisnya sebagai fakta yang terus hidup, dan tentunya bukan dianggap sebagai benda mati. Menjadikannya fakta yang terus hidup dan dihidupkan membuatnya menjadi objek kemanusiaan atau sosial kemanusiaan. Ilmu sosial sebagaimana dijelaskan Bourdieu (2011: 165) bisa mereduksi dunia sosial menjadi representasi yang dimiliki agen-agennya, 


\section{Jurnal Poetika Vol. III No. 2, Desember 2015}

dan tugas ilmu sosial selanjutnya adalah memproduksi sebuah laporan dari berbagai laporan yang diproduksi subjek-subjek sosial. Ilmu sosialnya sastra beserta dengan praktiknya adalah sebuah representasi dari subjek ilmuwan sosial sastra. Jurnal ilmu sastra Fakultas Ilmu Budaya adalah representasi dari ilmuwan sosial sastra, yaitu Faruk.

Buku sosiologi sastra menjadi buku yang selalu dipakai mahasiswa sastra dalam mempelajari persoalan sosial kesusastraan. Tetapi sayang dalam buku itu teori Bourdieu belum dimasukkan ke dalam bukunya. Sebagai ilmuwan sastra, Faruk giat juga membahas teori sosial sastra. Entah disadari atau tidak, beberapa teori sosial belum dimasukkan dan dieksprerimentasikan dalam buku dan penelitiannya. Pada volume pertamanya, jurnal itu menawarkan tiga teori sosial, yaitu Pierre Bourdieu, Alan Swingewood, dan Frederic Jameson.

Selain sebagai teoritikus sosial sastra, Faruk juga mendalami persoalan kefilsafatan yang dapat dilihat dalam buku awalnya tentang epistemologi sastra yang diterbitkan tahun 1988. Sekarang ia mengampu mata kuliah filsafat dan paradigma ilmu sastra. Minatnya yang mendalam dalam studi sastra, kefilsafatan, dan bahkan kesejarahan sastra, menstrukturasi bagaimana ia memilih. Pada volume I nomor 2 muncul etika Levinas dari tulisan Fawaid, Stephen Greenblat dari Fatoni, Guillen dari Purnamasari, dan tiga tulisan lain membahas sejarawan kritik.

Sebagai ilmuwan sastra, Faruk terus mengembangkan kajian sastra dan terus mengikuti perkembangan kajian sastra. Kondisi yang demikian membuat ia melakukan upaya pengembangan yang tercermin pada jurnal Poetika volume II dan III. Sebagai dosen pada program doktoral, Faruk mengajak mahasiswa pascasarjana baik yang program doktoral maupun yang master untuk mengikuti kajian mutakhir sastra dengan menjadikan teori mutakhir sebagai alat analisis. Usaha itu berhasil dengan terbitnya dua volume dengan kajian sastra mutakhir. Terbitnya dua volume terakhir tidaklah bebas dari selera pemilik modal atau kekuasaan.

Dalam jagad akademik, Faruk juga dikenal sebagai ilmuwan yang intens meneliti dengan teori pascakolonial. Dalam buku Belenggu Pasacakolonial, Hegemoni dan Resistensi dalam Sastra Indonesia, Faruk memakai teoriteori pascakolonial dan teori hegemoni untuk membaca teks-teks sastra. Beberapa bukunya, seperti Perlawanan Tak Kunjung Usai, Novel Indonesia: Kolonialisme dan Ideologi Emansipatoris, dan Belenggu Pascakolonial, adalah bukubuku yang secara metodis menggunakan dekonstruksi dalam praktik analisisnya. Dalam perkembangan akademiknya, Faruk sudah sampai pada paradigma pascastrukturalisme, pascakolonialisme, dan bahkan pascamodernisme yang dapat dilihat pada buku Sastra dalam Masyarakat (Ter-)multimedia(-kan): Implikasi teoritik, metodologis, dan edukasionalnya.

Posisinya yang demikian, yang sebagai sebuah modal secara simbolik dan kultural sudah terakumulasi sejak lama dan menjadi sebuah habitus, kemudian menstrukturasi dirinya dalam menentukan dan memilih mana yang penting dan mana yang tidak penting untuk diangkat. Kajian realisme magis Faris, pascakonial Sara Upstone, dan travel writing Carl Thomson adalah kajian yang berawal dari kajian pascakolonial. Realisme magis lahir dari proyek pascakolonial, juga Upstone, terlebih lagi travel writing yang muncul dari kebiasaan kolonial dalam mencari dan menguasai wilayah atau dunia baru. Sebagai ilmuwan sastra, Faruk berada dalam ruang kajian pascastrukturalisme, pascamodernisme, dan pascakolonialisme. Ruang kajian yang demikian menjadi ruang sosial keilmuannya. Dengan ruang itu, Faruk hadir sebagai pemegang kekuasaan simbolik dan kultural.

Kondisi di atas, sebagaimana dikatakan Bourdieu (2011: 182), adalah kondisi dimana kekuasaan simbolik bisa menjadi kekuasaan 


\section{Jurnal Poetika Vol. III No. 2, Desember 2015}

konstitusi, dalam pengertian ganda istilah ini sebagaimana menurut Dewey, yakni pengertian filosofis dan sekaligus politik, yaitu sebuah kekuasaan untuk melestarikan atau mentranspormasikan prinsip-prinsip objektif penyatuan dan pemisahan, perkawinan dan perceraian, asosiasi dan disasosiasi yang berlaku di dunia sosial; sebuah kekuasaan untuk melestarikan atau mentransformasi klasifikasi aktual soal jenis kelamin, bangsa, wilayah, umur, dan status sosial. Dalam dunia akademik dan dunia kritik akan terjadi hal yang demikian, yaitu kekuasaan untuk melestarikan sebuah prinsip dalam mempersepsi sebuah realitas atau mendefinisikan dan bahkan mereproduksi realitas sosial keakademikan.

Usaha itu dilakukan dan dimulai ketika Faruk menjadi pengelola program pascasarjana Ilmu Sastra dan membuat jurnal ilmu sastra. Bourdieu (2011: 183) mengatakan bahwa untuk mengubah dunia, orang harus mengubah cara membentuk dunia, yakni visi tentang dunia dan operasi-operasi praktis dalam memproduksi dan mereproduksi kelompok. Dunia akademik atau kritik sastra akan diubahnya ke arah yang lebih baru yang berbeda dengan sebelumnya, yakni ketika Pradopo dan kemudian Kun Zahrun menjadi pengelola program pascasarjana dengan paradigma strukturalisnya. Faruk mencoba melakukan perubahan cara pandang dan cara membentuk dunia sastra dan arenanya dalam jagad akademik atau kritik sastra. Hal itu dimungkinkan, melihat posisinya dalam ruang sosial keakademikan atau keilmuannya sebagai pemegang kekuasaan. Posisi demikian membuatnya tidak bisa menghindar dari sebuah relasi dengan sifat kekuasaan yang cenderung, sebagaimana dikatakan Bourdieu (2011: 179), mereproduksi dan memperkuat relasinya dalam ruang sosial. Dalam konteks jurnal itu, kekuatan dimiliki oleh Faruk sebagai pejabat, pengelola program pascasarjana Ilmu Sastra, dan pimpinan umum jurnal. Bourdieu (2011: 181) mengatakan bahwa di antara sekian banyak sudut pandang, terdapat satu sudut pandang resmi, yaitu sudut pandang para pejabat yang diekspresikan dalam wacana resmi. Jurnal Poetika adalah bentuk ekspresi wacana resmi kesusastraan dan kritik sastra. Sudut pandangnya terlembaga, dan melalui lembaga itu ia mendapatkan kepercayaan dari masyarakatnya. Masyarakat akademik menjadi agen bagi kekuasaan kultural dan simbolik dari pejabat tersebut. Implikasinya, akan terbangun sebuah kelompok, sebuah dunia, dan sebuah tatanan. Itulah yang disebut Bourdieu (2011: 182) sebagai sebuah kekuasaan simbolik dalam pengertian kekuasaan dalam membuat dunia.

$$
\text { Pembangunan atau pembentukan }
$$
sebuah dunia ini adalah upaya Faruk menyatukan dunia yang terpisah, antara masa lalu dan masa kini, antara tua dan muda, antara akademisi dan praktisi. Upaya tersebut pada arena yang lain membuatnya melakukan penyatuan antara penulis generasi tua dengan penulis generasi muda, dan bahkan dengan akademisi muda, juga akademsi tua. Dalam arena yang lain, pada sebuah diskusi bulanan sastra terjadi penyatuan antara teori yang relatif baru dengan teori lama, diperbicangkannya atau didiskusikannya kembali, baik pada level ontologis maupun pada level epistemologis. Semua itu adalah upaya sampai pada dunia ideal yang faktual sebagaimana dijelaskan sendiri oleh Faruk (2012) dalam buku terakhirnya, Novel Indonesia: Kolonialisme dan Ideologi Emansipatoris. Faruk bersama intelektual muda berusaha membuat dan mencapai bersama dunia ideal itu. Dengan sudut pandangnya sebagai pejabat, semua itu memungkinkan untuk diraih dalam arena (kritik) sastra yang ada dan yang mungkin diadakan.

\section{Kesimpulan}

Teks sastra dan penulisnya berada dalam sebuah arena, yaitu kritik sastra. Dalam dunia kritik, sebagai arena, ia hidup dan dihidupkan kembali. Sebagai contoh, Rendra dan Subagio Sastrowardoyo dihidupkan kembali ketika ia diobjektivikasi oleh kritikus, Rushdie dan 
Morrison diangkat kembali dengan perspektif yang lebih baru, dan Kris Budiman hadir sebagai yang diobjektivikasi dan mengobjektivikasi. Praktisi dan akademisi dihadirkan sebagai agen dalam dua tradisi dan dua sejarah, seperti dimunculkannya Akmal, Mashuri, Raharyoso. Universitas Gadjah Mada mempunyai sejarah dalam posisi dan disposisinya. Universitas Gadjah Mada dalam sejarah dirintis oleh sebagian mahaguru sastra yang kemudian membawa sastra Indonesia dalam kancah internasional. Dalam arena lain, Universitas Gadjah Mada mencetak atau melahirkan ilmuwan sastra, akademisi, praktisi sastra yang semua itu menjadi habitus Universitas Gadjah Mada yang menstrukturkan tindakan atau praktiknya dalam arena kritik sastra Indonesia.

Dalam perkembangannya, salah satu strategi dalam reproduksi dunia arena (kritik) sastra Indonesia adalah strategi menjadi pemilik modal atau pemegang kekuasaan, yaitu kekuasaan simbolik. Dalam jurnal Poetika, Faruk menjadi pejabat yang dengan sudut pandangnya melakukan pergerakan ke arah dunia kritik yang berbeda dengan pejabat terdahulu, yaitu kritik dengan paradigma pascastrukturalisme, pascakolonialisme, dan pascamodernisme. Paradigma itu secara eksplisit muncul dalam hampir semua bukunya dan yang kemudian membuatnya memasukkan paradigma tersebut ke dalam jurnal Poetika, sehingga tulisan-tulisan yang dipilih kemudian adalah tulisan dengan paradigma tersebut. Munculnya kritik sastra dengan teori Bourdieu adalah sebuah kontrol kritik atas fenomena sosial kesusastraan dan kritik sastra, yang dalam cara pandang tertentu membuat kita curiga atas fenomena yang mengemuka.

\section{Daftar Pustaka}

Akmal, Ramaida. 2013. Kririk Sastra Marxis Frederik Jameson: Teori dan Aplikasinya. Poetika, Jurnal Ilmu Sastra. Volume 1 Nomor 1, Juli 2013, pp. 73-87. UGM: Program Studi S2 Ilmu Sastra.
Atmosudiro, Sumijati dkk. 2006. Repertoire Fakultas Ilmu Budaya. Yogyakarta: Unit Penerbitas dan Perpustakaan Universitas Gadjah Mada.

Bourdieu, Pierre. 2011. Chose Dites; Urain dan Pemikiran. Rochan Sjams (penerjemah). Yogyakarta: Kreasi Wacana.

Bourdiu, Pierre. 2012. Arena Produksi Kultural, Sebuah Kajian Sosiologi Budaya. Yudi Santosa (penerjemah). Yogyakarta: Kreasi Wacana.

Faruk. 2012. Metode Penelitian Sastra, Sebuah Penjelajahan Awal. Yogyakarta: Pustaka Pelajar. 2012. Novel Indonesia, Kolonialisme dan Ideologi Emansipatoris. Yogyakarta: Ombak.

2012. Pengantar Sosiologi Sastra dari strukturalisme Genetik sampai Postmodernisme. Yogyakarta: Pustaka Pelajar.

2011. Sastra dalam Masyarakat (Ter-) Multimedia (-kan). Ypgyakarta: Pustaka Pelajar.

2007. Belenggu Pascakolonial, Hegemoni dan Resistensi dalam Sastra Indonesia. Yogyakarta: Pustaka Pelajar.

1995. Perlawanan Tak Kunjung Usai, Sastra Politik Dekonstruksi. Yogyakarta: Pustaka Pelajar.

Fawaid, Achmad.2013. Perjumpaan Etis dengan Wajah Yang-Lain: Membaca Karya Sastra dengan Etika Levinasian. Poetika, Vol 1 No 2 Desember 2013 pp 158-170. UGM: Program Studi S2 Sastra

Kris Budimam. 2013. Membaca (-Ulang) sebuah Puisi Pamplet Rendra "Sajak Sebatang Lisong". Poetika, Vol 1 No 2 Desember 2013 pp. 138-144. UGM: Program Studi S2 Ilmu Sastra.

Mashuri, 2013. Dekonstruksi Wayang dalam Novel Durga Umayi. Poetika, Jurnal Ilmu Sastra, Vol 1 No 1, Juli 2013, pp 16-36. UGM: Pascasarjana Ilmu Sastra.

Mashlihatin, Anis. 2014. Penggambaran Dunia dalam Novel Perjalanan "99 Cahaya di Langit Eropa.'Vol III Nomor 1 Juli 2015, pp 
Jurnal Poetika Vol. III No. 2, Desember 2015

1-21.UGM: Program Studi Ilmu Sastra.

Prasetyo, Arif Bagus. 2013. Metakritik Untuk

Subagio Sastrowardoyo. Poetika, Vol 1 No

2, Desember 2013. Pp. 119-137. UGM:

Program Studi S2 Ilmu Sastra.

Raharyoso, Dwi. Paradoks Ruang Tubuh dalam

Puisi Sakramen Karya Joko Pinurbo Kajian

Pascakolonial Tubuh Sara Upston. Vol II

No 2 Agustus 2014 pp 157-169. UGM

Program Studi S2 Ilmu Sastra.

Saputra, Imam Hendra. 2013. Realisme Magis dalam Novel The Satanic Verses karya Salam Rushdie. Vol II No 1 April 2014 pp 1-11. UGM: Program Studi S2 Ilmu Sastra.

Zen Hae. 2013. Pembicaraan Ringkas Puisi-Puisi Subagio Sastrowardoyo. Poetika, Vol 1 No 2, Desember 2013, pp. 107-118. UGM: Program Studi S2 Ilmu Sastra. 